\title{
DAMPAK CURAH HUJAN TERHADAP PRODUKTIVITAS TANAMAN PADI SAWAH PADA MASYARAKAT PETANI DI DESA LAMBO-LEMO KECAMATAN SAMATURU KABUPATEN KOLAKA
}

\author{
Ishak $^{1}$
}

\section{${ }^{1}$ Alumni Pendidikan Geografi FKIP UHO}

\begin{abstract}
Abstrak: Penelitian ini bertujuan untuk menganalisis dampak curah hujan terhadap produktivitas tanaman padi Di Desa Lambo-lemo. Dan agar dapat menemukan solusi yang tepat dalam melakukan upaya-upaya menghadapi curah hujan di Desa Lambolemo. Populasi penelitian ini adalah masyarakat yang berdomisili di Desa Lambolemo dan pengambilan sampel dari 123 Kepala Keluarga (KK) yang menjadi populasi kemudian dipilih 25\% sebagai sampel penelitian (31 Jiwa). Metode yang digunakan dalam penelitian ini adalah pembagian kuisioner, wawancara, dan dokumentasi. Analisis data menggunakan analisis deskriptif kualitatif. Dampak Curah hujan merupakan salah satu faktor utama yang menjadi penyebab menurunnya produktivitas tanaman padi desa Lambo-lemo, Hingga sampai saat ini pertanian padi Desa Lambolemo baru berkembang pesat dengan skala kegiatan yang sudah maju pula dan mengarah pada model bertani moderen, dan mendapatkan perhatian pemerintah setempat. Dengan adanya penelitian ini, pertanian padi Desa Lambo-lemo diharapkan dapat lebih meningkat lagi sehingga bisa memberikan peluang pekerjaan untuk masyarakat dan meningkatkan pendapatan masyarakat, juga perekonomian di desa tersebut. Berdasarkan hasil penelitian didapat bahwa curah hujan sampai saat ini masih menjadi faktor naik, turunya produktivitas tanaman padi di Desa Lambo-lemo.
\end{abstract}

Kata Kunci : Dampak curah hujan terhadap produkitivitas, Tanaman padi. 


\title{
IMPACT OF RAINFALL ON THE PRODUCTIVITY OF RICE CROPS IN FARMING COMMUNITIES IN THE VILLAGE OF LAMBO-LEMO SUB- DISTRICT SAMATURU KOLAKA DISTRICT Ishak $^{1}$
}

\author{
${ }^{1}$ AlumnusGeography EducationFKIP UHO
}

\begin{abstract}
The problems in this research are formulated as follows: 1) how the impact of rainfall on rice productivity in Lambo-lemo? 2). How are the efforts done by the rice farming community in Lambo-lemo village in the face of the change of bad rainfall? This study aims to analyze the impact of rainfall on the productivity of rice crops in the village lambo-lemo and in order to find the right solution in efforts to deal with rainfall in Lambo-lemo village. The population of this study were people living in lambo-lemo village and sampling from 123 family heads who were then selected $25 \%$ as research sample (31 people) The method used in this research is the division of questionnaires,interview, and documentation. Data analysis used qualitative descriptive analysis. The impact of rainfall is one of the main factors causing declining productivity of Lambo-lemo rice crops to date rice farming in Lambo-lemo village is expected to increase further so that it can provide job opportunities for the community and increase people's income also the economy of the village. Based on the results obtained that rainfall to date is still a factor of ups and downs of rice productivity in the village Lambo-lemo.
\end{abstract}

Keywords: Impact of rainfall on productivity, rice crop

\section{PENDAHULUAN}

Curah hujan adalah jumlah air hujan yang turun pada suatu daerah dalam waktu tertentu. Alat untuk mengukur banyaknya curah hujan adalah rain guage. Curah hujan dapat diukur dalam jam, hari, bulan, bahkan tahunan.Berkembangnya perindustrian dalam bidang pangan di Indonesia yang merupakan daerah khatulistiwa dengan berbagai jenis tanaman yang ada di Indonesia terutama di daerah pegunungan dan desa-desa tentunya curah hujan yang ada juga mempengaruhi hasil panen dan bertumbuhnya tanaman tersebut.
Di Indonesia banyak sekali terdapat tanaman yang kurang sehat padahal terletak dikawasan khatulistiwa, dimana biasanya banyak vegetasi yang mudah tumbuh. Hal ini disebabkan karna pada waktu penanaman tidaklah tepat dan juga tidak memperhatikan curah hujan yang ada. Di negara-negara lain banyak sekali terdapat tanaman yang hasil buahnya sangat bagus dan terlihat hijau, dikarnakan mereka menanam dengan memperhatikan beberapa aspek dalam bercocok tanam sehingga hasilnya sesuai dengan yang diharapkan.

Seringkali terjadi kesalahan dalam waktu pemberian pupuk dan saat 
menanam tanaman. Hal tersebut dikarnakan para petani hanya mengandalkan pengalaman saja, sehingga dapat menyebabkan banyak kerugian yang dialami oleh petani. Oleh sebab itu diperlukan sebuah alat pengukur curah hujan untuk dapat membantu para petani dalam mengetahui pola curah hujan pada suatu tempat dalam hal ini adalah tempat para petani tersebut menanam tanamannya.

Dengan mengetahui pola curah hujan para petani dapat menentuan jadwal tanam, pola tanam, musim tanam, panen, pengolahan hasil pertanian sampai pengangkutan atau pendistribusian hasil pertanian. Dari informasi curah hujan ini diharapkan dapat membantu para petani dalam menentukan waktu tanam dan dapat mengatur pola jenis tanaman yang disesuaikan dengan kebutuhan air bagi tanaman yang akanditanam.

Peranan air dalam kehidupan sangatlah besar. Mekanisme kompleks kehidupan tidak mungkin berfungsi tanpa kehadiran cairan yang berupa air. Bagian besar bumi dan mahluk hidup juga terdiri atas air. Air yang berasal dari hujan merupakan fenomena alam yang paling penting bagi terjadinya kehidupan di bumi. Butiran hujan selain membawa molekul air juga banyak membawa materi yang penting bagi kehidupan, seperti material pupuk yang lengkap bagi tumbuhan.

Dari apa yang tertulis di atas manfaat air hujan sangatlah penting bagi kehidupan dan pertanian. Oleh sebab itu dengan kita bisa mengamati curah hujan pada suatu tempat secara otomatis dan tercatat dalam sebuah database, sehingga data curah hujan belum dapat kita manfaatkan secara optimal.

Salah satu fenomena yang terlihat pada masyarakat petani padi di Desa Lambo-lemo Berdasarkan hasil observasi awal ialah tingkat Pengolahan sawah yaitu masih tergolong menengah kebawah. Hal ini ditandai dengan proses penggarapan lahan masih dalam kategori tradisional.

Berdasarkan uraian tersebut diatas, maka penulis merasa tertarik untuk melakukan penelitian sehubungan dengan "Dampak curah hujan terhadap produktivitas tanaman padi sawah pada masyarakat petani di desa lambo-lemo kecamatan samaturu kabupaten kolaka".

Curah hujan adalah jumlah air yang jatuh di permukaan tanah datar selama periode tertentu yang diukur dengan satuan tinggi milimeter ( $\mathrm{mm}$ ) di atas permukaan horizontal. Dalam penjelasan lain curah hujan juga dapat diartikan sebagai ketinggian air hujan yang terkumpul dalam tempat yang datar, tidak menguap, tidak meresap dan tidak mengalir. Indonesia merupakan negara yang memiliki angka curah hujan yang bervariasi dikarenakan daerahnya yang berada pada ketinggian yang berbeda-beda. Curah hujan 1 (satu) milimeter, artinya Dalam luasan satu meter persegi pada tempat yang datar tertampung air setinggi satu milimeter termpat yang datar tertampung air setinggi satu milimeter atau Tertampung Air Satu Sengah Liter

Menurut Linsley (1996: 49), jenisjenis hujan berdasarkan intensitas curah hujan, yaitu: 
1) Hujan ringan, kecepatan jatuh sampai $2,5 \mathrm{~mm} / \mathrm{jam}$;

2) Hujan menengah, dari $2,5-7,6$ $\mathrm{mm} / \mathrm{jam}$.

3) Hujan lebat, lebih dari 7,6 $\mathrm{mm} / \mathrm{jam}$.

Kebutuhan makanan pokok setiap penduduk di seluruh penjuru dunia ini satu samalain berbeda, dan salah satu kebutuhan makanan pokok tersebut adalah beras atau nasi yang merupakan makanan pokok sebagian besar penduduk Indonesia. Beras adalah buah padi yang berasal dari golongan rumput - rumputan (gramineae) yang sudah banyak dibudidayakan di Indonesia. (Arsyad, 2010) Padi (Bahasa latin: Oryza sativa) merupakan salah satu tanaman budidaya terpenting dalam peradaban. Meskipun terutama mengacu pada jenis tanaman budidaya, padi juga digunakan untuk mengacu pada beberapa jenis dari marga (genus) yang sama, yang biasa disebut sebagai padi liar. Padi diduga berasal dari India atau Indocina dan masuk ke Indonesia dibawa oleh nenek moyang yang migrasi dari daratan Asia sekitar 1500 SM.

Produksi padi dunia menempati urutan ketiga dari semua serealia, setelah jagung dan gandum. Namun demikian, padi merupakan sumber karbohidrat utama bagi mayoritas penduduk dunia. Teknik budidaya padi telah dikenal oleh manusia sejak ribuan tahun yang lalu. Sejumlah sistem budidaya diterapkan untuk padi. Budidaya padi sawah diduga dimulai dari daerah lembah Sungai Yangtse di Tiongkok. Budidaya padi lahan kering, dikenal manusia lebih dahulu daripada budidaya padi sawah. Budidaya padi lahan rawa, dilakukan di beberapa tempat di Pulau Kalimantan. Bercocok tanam padi mencakup persemaian, pemindahan atau penanaman, pemeliharaan (termasuk pengairan, penyiangan, perlindungan tanaman, serta pemupukan), dan panen. Aspek lain yang penting namun bukan termasuk dalam rangkaian bercocok tanam padi adalah pemilihan kultivar, pemrosesan biji dan penyimpanan biji. (Wikipedia,2010)

Sumber daya air yang ada di sungai-sungai yang memiliki daerah irigasi harus dimanfaatkan sedemikian sehingga semua kepentingan penggunaan air dari sungai tersebut dapat berjalan tanpa adanya konflik pemanfaatan antara kepentingan yang satu dengan yang lainnya. Pemanfaatan air untuk irigasi harus dilakukan sedemikian rupa melalui operasi jaringan irigasi untuk menjamin bahwa air yang tersedia cukup untuk luasan areal tanaman, hemat dalam distribusinya serta tersedia secara berkesinambungan.

Operasi Jaringan Irigasi adalah upaya pengaturan air pada jaringan irigasi yang meliputi penyediaan, pembagian, pemberian, penggunaan, konservasi dan pembuangannya termasuk kegiatan membuka, dan menutup pintu bangunan irigasi, menyusun rencana tata tanam, menyusun sistem golongan, menyusun rencana pembagian air, kalibrasi, pengumpulan data, pemantauan dan evaluasi. Berdasarkan uraian tersebut, Rencana Pola Tanam merupakan salah satu dari kegiatan operasi jaringan irigasi yang harus dibuat untuk setiap musim tanam guna pemanfaatan air irigasi secara efektif, efisien, dan berkesinambungan tanpa konflik pemanfaatan air. Untuk menentukan Pola Tanam perlu dilakukan Perhitunngan Neraca Air, Kebutuhan Air Untuk Irigasi, Kebutuhan Air Untuk Penyiapan Lahan, dan 
Kebutuhan Air Untuk Pertumbuhan Tanaman Padi. (Ditjen Pengairan, 1982)

\section{METODE PENELITIAN}

Penelitian ini telah dilaksanakan pada tanggal 19 maret 2017 sampai 26 maret 2017 di desa Lambo-lemo kecamatan samaturu kabupaten kolaka

jenis Penelitian yang digunakan dalam penelitian ini adalah Analisis deskriptif kualitatif.Populasi adalah seluruh data yang menjadi perhatian peneliti dalam suatu ruang lingkup, dan waktu yang sudah ditentukan. Senada dengan pendapat diatas, sugiyono (2002) dalam kasmadi (2013:65), mengemukakan, populasi adalah wilayah generalisasi yang terdiri atas obyek/subyek yang memiliki kuantitas dan karakteristik tertentu yang ditetapkan oleh peneliti untuk dipelajari dan kemudian ditarik kesimpulannya.

Populasi yang dimaksud dalam penelitian ini adalah masyarakat bermata pencaharian sebagai Petani Padi Sawah yang tinggal Di Desa Lambo-lemo dengan Jumlah populasi yaitu 123 orang Kepala Keluarga (KK).

Menurut Sugiyono (2002) dalam kasmadi (2013:66), sampel adalah sebagian dari jumlah dan karakteristik yang dimiliki oleh populasi tersebut. Menurut Arikunto (2006:112), Jika populasi kurang dari 100 maka sampel diambil seluruhnya, dan apabila populasi lebih dari 100 maka dapat diambil sampel sebesar $10-15 \%$ atau 20-25\%.

Pengambilan sampel dalam penelitian ini yaitu menggunakan randomsampling, yaitu sebanyak $25 \%$ dari jumlah populasi yang ada,dengan demikian banyaknya sampel dalam penelitian ini adalah :

$$
\frac{25}{100} \times 123=31 \text { Orang }
$$

(Sugiyono Dalam Riduwan, 2009:57)

Sehingga diperoleh jumlah sampel 31 orang ditarik sampel secara random sampling dimana dalam menentukan jumlah sampel memberikan peluang kepada setiap unsur populasi yang terpilih sebagai sampel dengan cara acak (Sugiyono,1997:67). Penelitian ini bertujuan untuk mengetahui "Dampak Curah hujan terhadap Produktivitas tanaman padi sawah pada masyarakat petani padi di Desa Lambo-Lemo Kecamatan Samaturu Kabupaten Kolaka" maka hanya keluarga petani sawah yang dapat dijadikan sampel penelitian ini.

Adapun teknik yang digunakan dalam pengumpulan data penelitian adalah menggunakan data primer yaitu data yang diperoleh dengan melakukan penelitian langsung terhadap obyek penelitian dengan menggunakan teknik pengumpulan data sebagai berikut:

a. Observasi

Observasi adalah alat pengumpul data yang dilakukan dengan cara mengamati dan mencatat secara sistematik gejala-gejala yang diselidiki. Dalam hal ini, observasi dilakukan untuk mengamati langsung dan kondisi lokasi penelitian terutama mengenai dampak curah hujan terhadap produktifitas tanaman padi sawah pada masyarakat petani di desa lambo-lemo kecamatan samaturu kabupaten kolaka.

b. Angket

Angket adalah pengumpulan data yang berupa daftar pertanyaan tertulis yang tersusun dan disebarkan untuk mendapat informasi dari sumber data atau responden (Suharsimi Arikunto,2002: 128). Metode ini 
digunakan untuk mendapatkan data tentang dampak curah hujan terhadap produktivitas tanaman padi sawah melalui pertanyaan-pertanyaan secara tertulis yang digunakan untuk memperoleh informasi dari responden di Desa Lambo-lemo Kecamatan samaturu Kabupaten Kolaka.

\section{c. Wawancara}

Menurut Esterberg (2002) : wawancara adalah pertemuan antara dua orang untuk bertukar informasi dan ide melalui tanya jawab sehingga dapat dikontruksikan makna dalam suatu topik tertentu. Dalam wawancara peneliti menemui salah satu narasumber yang merupakan masyarakat setempat dan pelaku petani di Desa penelitian,sesuai dengan syarat wawancara.

d. Dokumentasi adalah pemberian atau pengumpulan bukti dan keterangan, seperti gambar, kutipan, dan lain sebagainya yang menyangkut data penelitian selama meneliti. Dalam dokumentasi peneliti melakukan pengambilan gambar,dan data tertulis,sebagai bukti bahwa peneliti benar-benar melakukan penelitian di tempat penelitian tersebut.

Data yang diperoleh melalui kuisioner, wawancara,dan dokumentasi dikumpul dan diolah dengan menggunakan analisis deskriptif, yaitu analisis data hasil penelitian yang menggambarkan tentang kondisi keadaan lahan pertanian di desa penelitian yang memberikan peranan terhadap peluang pekerjaan dan kondisi ekonomi masyarakat.

Untuk menghitung jumlah atau frekuensi dari masing-masing jawaban dalam kuesioner, kemudian persentase jawaban responden dengan menggunakan rumus yang di kemukakan oleh Hartonno (dalam Sunarna, 2010: 6), yaitu digunakan rumus sebagai berikut:

$$
P=\frac{\mathrm{f}}{\mathrm{N}} \times 100 \%
$$

Keterangan:

P: Persentase

f.: Frekuensi data

$\mathrm{N}$ : Jumlah sampel yang diolah

\section{HASIL PENELITIAN}

Tabel 3.1 Produktifitas Padi Dan curah Hujan Tahunan

\begin{tabular}{|c|c|c|c|c|c|c|c|}
\hline No. & Thn & $\begin{array}{l}\text { Curah } \\
\text { Hujan } \\
\text { (Thn) }\end{array}$ & $\begin{array}{l}\text { Luas } \\
\text { Lahan } \\
\text { (Ha) }\end{array}$ & $\begin{array}{l}\text { Luas } \\
\text { Tanam } \\
\text { (Ha) 2x } \\
\text { Tnm }\end{array}$ & $\begin{array}{l}\text { Luas } \\
\text { Panen } \\
\text { (Ha) }\end{array}$ & $\begin{array}{l}\text { Produksi } \\
\text { (Ton) }\end{array}$ & $\begin{array}{l}\text { Produktivi } \\
\text { tas Ton } \\
\text { (Ha) GKP* }\end{array}$ \\
\hline 1. & 2012 & $\begin{array}{l}1660 \\
\mathrm{~mm}\end{array}$ & $132 \mathrm{Ha}$ & $264 \mathrm{Ha}$ & $264 \mathrm{Ha}$ & $\begin{array}{c}1414,8 \\
\text { Ton }\end{array}$ & 5,4 Ton \\
\hline 2. & 2013 & $\begin{array}{l}1917,9 \\
\mathrm{~mm}\end{array}$ & $132 \mathrm{Ha}$ & $264 \mathrm{Ha}$ & $264 \mathrm{Ha}$ & $\begin{array}{c}1561,2 \\
\text { Ton }\end{array}$ & 6,3 Ton \\
\hline 3. & 2014 & $\begin{array}{l}2162,7 \\
\mathrm{~mm}\end{array}$ & $132 \mathrm{Ha}$ & $264 \mathrm{Ha}$ & $264 \mathrm{Ha}$ & $\begin{array}{c}1699,9 \\
\text { Ton }\end{array}$ & 6,4 Ton \\
\hline 4. & 2015 & $\begin{array}{l}3305,5 \\
\mathrm{~mm}\end{array}$ & $132 \mathrm{Ha}$ & $264 \mathrm{Ha}$ & $264 \mathrm{Ha}$ & $\begin{array}{c}1320,3 \\
\text { Ton }\end{array}$ & 4,8 Ton \\
\hline \multirow[t]{2}{*}{5.} & 2016 & $\begin{array}{l}2.109 \\
\mathrm{~mm}\end{array}$ & $132 \mathrm{Ha}$ & $264 \mathrm{Ha}$ & $264 \mathrm{Ha}$ & $\begin{array}{c}1809,2 \\
\text { Ton }\end{array}$ & 6,8 Ton \\
\hline & Jmlh & & $660 \mathrm{Ha}$ & $1320 \mathrm{Ha}$ & $\begin{array}{l}1320 \\
\mathrm{Ha}\end{array}$ & & \\
\hline
\end{tabular}


Data : Data Produktifitas Padi Dari Berbagai Tahun Diolah

*Gabah Kering Panen.

Dari tabel diatas menujukkan bahwa luas areal tanaman padi pada tahun 2012 Yaitu sebesar $132 \mathrm{Ha}$ Dengan Hasil Produksi 1414,8 Ton Produktivitasnya sebesar 5,4 Ton/Ha, dengan curah hujan pada tahun 2012 sebesar $1660 \mathrm{~mm}$, sementara pada tahun 2013 luas areal tanaman padi yaitu sebesar 132 Ha Dengan Hasil Produksi 1561,2 Ton Produktivitasnya Sebesar 6,3 Ton/Ha, dengan Curah hujan pada tahun 2013 sebesar 1917,9 mm, sementara pada tahun 2014 Luas Tanaman Padi yaitu sebesar $132 \mathrm{Ha}$ Dengan Hasil Produksi 1699,9 Ton
Produktivitasnya sebesar $6,4 \mathrm{Ton} / \mathrm{Ha}$, dengan curah hujan pada tahun 2014 sebesar 2162,7 mm, sementara pada tahun 2015 luas tanaman padi yaitu sebesar 132 Ha Dengan Hasil Produksi 1320,3 TonProduktivitasnya sebesar 4,8 Ton/ Ha, Dengan Curah Hujan Pada Tahun 2015Sebesar 3305,5 mm, dan sementara pada tahun 2016 luas areal tanaman padi sebesar $132 \mathrm{Ha}$ Dengan HasiL Produksi 1809,2 Ton Produktivitasnya Sebesar 6,8 Ton/Ha, Dengan Curah Hujan pada tahun 2016 sebesar $2.109 \mathrm{~mm}$.

Tabel 3.2 Produksi Padi dan curah hujan tahunan

\begin{tabular}{lllll}
\hline No. & $\begin{array}{l}\text { Tanam Hingga Panen } \\
\text { Pada Tahun 2012 }\end{array}$ & $\begin{array}{l}\text { Data Curah } \\
\text { Hujan Bulanan }\end{array}$ & $\begin{array}{l}\text { Curah hujan } \\
\text { rata-rata }\end{array}$ & $\begin{array}{l}\text { Produktsi } \\
\text { Ton }\end{array}$ \\
\hline 1. & Januari & $130 \mathrm{~mm}$ & & \\
\hline & Februari & $240 \mathrm{~mm}$ & & \\
\hline Maret & $350 \mathrm{~mm}$ & & \\
\hline April & $190 \mathrm{~mm}$ & & \\
\hline Mei & $150 \mathrm{~mm}$ & & \\
\hline Juni & $220 \mathrm{~mm}$ & & \\
\hline 2. & Juli & $80 \mathrm{~mm}, 33 \mathrm{~mm}$ & Ton \\
\hline & Agustus & $-\mathrm{mm}$ & & \\
\hline & September & - & $\mathrm{mm}$ & \\
\hline & Oktober & $120 \mathrm{~mm}$ & & \\
\hline & November & $110 \mathrm{~mm}$ & $\mathbf{1 4 1 4 , 8}$ ton \\
\hline
\end{tabular}

Data : Diolah dari Hasil penelitian 2017

Dari Tabel diatas dapat dilihat bahwa Pada bulan Januari curah hujannya sebanyak $130 \mathrm{~mm}$, bulan Februari sebanyak $240 \mathrm{~mm}$, bulan maret curah hujannya $350 \mathrm{~mm}$, bulan april curah hujannya $190 \mathrm{~mm}$, bulan mei curah hujannya $150 \mathrm{~mm}$, dan bulan juni curah hujannya $220 \mathrm{~mm}$, kemudian penanaman kedua mulai di 
lakukan pada bulan juli curah hujannya sebanyak $80 \mathrm{~mm}$, bulan agustus tidak terjadi hujan, di susul pada bulan September juga tidak terjadi hujan, bulan oktober curah hujannya $120 \mathrm{~mm}$, bulan november sebanyak $110 \mathrm{~mm}$, dan bulan Desember sebanyak $70 \mathrm{~mm}$ Maka Untuk Mengetahui nilai Q maka dapat dihitung dengan rumus sebagai berikut

$$
\begin{gathered}
Q=\frac{\text { Jumlah rata-rata bulan kering }}{\text { jumlah rata-rata bulan basah }} \times 100 \% Q=\frac{2}{8} \times 100 \% \\
\text { Nilai } Q=25 \%
\end{gathered}
$$

Maka dapat di ketahui bahwa pada tabel diatas menunjukkan bahwa curapada tahun 2012 yaitu hujan bertipe iklim B Yaitu Basah, vegetasinya hutan hujan tropis. Sehinga dapat dilihat pada tabel diatas bahwa produksi padi pada tahun 2012 , dimana curah hujan rata-rata pada waktu penanaman pertama sebesar 213,33 $\mathrm{mm}$ dan menghasilkan produksi padi sebanyak 727,4 ton, sementara pada waktu penanaman kedua curah hujan rata-rata $63,33 \mathrm{~mm}$ dan menghasilkan produksi padi sebanyak 687,4 ton, dan untuk mendapatkan hasil produksi yang terbaik yaitu minimal curah hujan ratarata $200 \mathrm{~mm} / \mathrm{sekali}$ panen. Untuk mendapatkan hasil produksi/panen yang baik rata-rata curah hujan berkisar antara 1500-2000 mm/ tahun jika lebih dan kurang yang dimaksud maka produksi tidak bagus, atau bisa saja gagal panen, kemudian jika curah hujan kurang dari $200 \mathrm{~mm} /$ bulan maka juga akan berdampak pada terhadap produksi

\begin{tabular}{|c|c|c|c|c|}
\hline No. & $\begin{array}{l}\text { Tanam Hingga } \\
\text { Panen Pada Tahun } \\
2013\end{array}$ & $\begin{array}{l}\text { Data Curah } \\
\text { Hujan Bulanan }\end{array}$ & $\begin{array}{l}\text { Curah hujan } \\
\text { rata-rata }\end{array}$ & $\begin{array}{l}\text { Produktsi } \\
\text { Ton }\end{array}$ \\
\hline \multirow[t]{6}{*}{1.} & Januari & $\mathrm{mm}$ & & \\
\hline & Februari & $\mathrm{mm}$ & & \\
\hline & Maret & $310 \mathrm{~mm}$ & & \\
\hline & April & $325 \mathrm{~mm}$ & & \\
\hline & Mei & $421 \mathrm{~mm}$ & & \\
\hline & Juni & $135,5 \mathrm{~mm}$ & $256,9 \mathrm{~mm}$ & 793,35 ton \\
\hline \multirow[t]{7}{*}{2.} & Juli & $60 \quad \mathrm{~mm}$ & & \\
\hline & Agustus & $\mathrm{mm}$ & & \\
\hline & September & $-\quad \mathrm{mm}$ & & \\
\hline & Oktober & $140 \mathrm{~mm}$ & & \\
\hline & November & $85,5 \mathrm{~mm}$ & & \\
\hline & Desember & $90 \quad \mathrm{~mm}$ & $62,58 \mathrm{~mm}$ & 767,85 ton \\
\hline & Total & $1917 \mathrm{~mm}$ & $319,48 \mathrm{~mm}$ & 1561,2 ton \\
\hline
\end{tabular}

Tabel 3.3 Produksi Padi dan curah hujan tahunan

Data : Diolah dari Hasil penelitian 2017 
Dari Tabel diatas dapat dilihat bahwa Pada bulan Januari curah hujannya sebanyak $120 \mathrm{~mm}$, bulan Februarisebanyak $230 \mathrm{~mm}$, bulan maret curah hujannya $310 \mathrm{~mm}$, bulan april curah hujannya $325 \mathrm{~mm}$, bulan mei curah hujannya $150 \mathrm{~mm}$, dan bulan juni curah hujannya $135,5 \mathrm{~mm}$, kemudian penanaman kedua, mulai di lakukan pada bulan juli curah hujannya sebanyak $60 \mathrm{~mm}$, bulan agustus tidak terjadi hujan, di susul pada bulan September juga tidak terjadi hujan, bulan oktober curah hujannya sebanyak $140 \mathrm{~mm}$, bulan November sebanyak $85,5 \mathrm{~mm}$, dan bulan Desember sebanyak $90 \mathrm{~mm}$.

Maka Untuk Mengetahui nilai Q maka dapat dihitung dengan rumus sebagai berikut :

$\mathrm{Q}=\frac{\text { Jumlah rata-rata bulan kering }}{\text { jumlah rata-rata bulan basah }} \mathrm{X} 100 \%$

$$
\mathrm{Q}=\frac{3}{7} \times 100 \%
$$

Nilai $Q=42 \%$
Maka dapat di ketahui bahwa pada tabel diatas menunjukkan bahwa curah hujan bertipe iklim C agak basah, vegetasinya hutan rimba

Sehinga dapat dilihat pada tabel diatas bahwa produksi padi pada tahun 2013, dimana curah hujan rata-rata pada waktu penanaman pertama sebesar 256,9 $\mathrm{mm}$ dan menghasilkan produksi padi sebanyak 793,35 ton, sementara pada waktu penanaman kedua curah hujan rata-rata $62,58 \mathrm{~mm}$ dan menghasilkan produksi padi sebanyak 767,85 ton, dan untuk mendapatkan hasil produksi yang terbaik yaitu minimal curah hujan ratarata $200 \mathrm{~mm} / \mathrm{sekali}$ panen. Untuk mendapatkan hasil produksi/panen yang baik rata-rata curah hujan berkisar antara 1500-2000 mm/ tahun jika lebih dan kurang yang dimaksud maka produksi tidak bagus, atau bisa saja gagal panen, kemudian jika curah hujan kurang dari $200 \mathrm{~mm} /$ bulan maka juga akan berdampak pada terhadap produksi

Tabel 3.4 Produksi Padi dan curah hujan tahunan

\begin{tabular}{lllll}
\hline No. & Tanam Hingga Panen & Data Curah & Curah hujan & Produktsi \\
Pada Tahun 2014 & Hujan Bulanan & rata-rata & Ton
\end{tabular}

\begin{tabular}{llllll}
\hline 1. & Januari & 195 & $\mathrm{~mm}$ & & \\
\hline & Februari & 235 & $\mathrm{~mm}$ & & \\
\hline Maret & 435 & $\mathrm{~mm}$ & & \\
\hline April & $320,5 \mathrm{~mm}$ & & \\
\hline Mei & $104,7 \mathrm{~mm}$ & & \\
\hline & Juni & 365 & $\mathrm{~mm}$ & $275,86 \mathrm{~mm}$ & 854,95 ton \\
\hline $\mathbf{2 .}$ & Juli & - & $\mathrm{mm}$ & & \\
\hline & Agustus & - & $\mathrm{mm}$ & & \\
\hline & September & $107,5 \mathrm{~mm}$ & & \\
\hline Oktober & 221 & $\mathrm{~mm}$ & & $\mathbf{1 6 9 9 , 9}$ ton
\end{tabular}


Data :Diolah dari Hasil penelitian 2017

Dari Tabel diatas dapat dilihat bahwa Pada bulan Januari curah hujannya sebanyak $195 \mathrm{~mm}$, bulan Februarisebanyak $235 \mathrm{~mm}$, bulan maret curah hujannya $435 \mathrm{~mm}$, bulan april curah hujannya $320,5 \mathrm{~mm}$, bulan mei curah hujannya 104,7 mm, dan bulan juni curah hujannya 365 mm, kemudian penanaman kedua, mulai di lakukan pada bulan juli curah hujannya sebanyak - $\mathrm{mm}$, bulan agustus tidak terjadi hujan, di susul pada bulan September curah hujannya sebanyak $107,5 \mathrm{~mm}$, bulan oktober curah hujannya sebanyak $221 \mathrm{~mm}$, bulan November sebanyak $397 \mathrm{~mm}$, dan bulan Desember sebanyak 237 $\mathrm{mm}$.

Maka Untuk Mengetahui nilai Q maka dapat dihitung dengan rumus sebagai berikut : $100 \%$

$$
\mathrm{Q}=\frac{\text { Jumlah rata-rata bulan kering }}{\text { jumlah rata-rata bulan basah }} \mathrm{x}
$$

$$
\mathrm{Q}=\frac{2}{10} \times 100 \%
$$

Nilai $\mathrm{Q}=20 \%$

Maka dapat di ketahui bahwa pada tabel diatas menunjukkan bahwa curah hujan bertipe iklim B yaitu basah, vegetasinya hutan hujan tropis.Sehinga dapat dilihat pada tabel diatas bahwa produksi padi pada tahun 2014, dimana curah hujan rata-rata pada waktu penanaman pertama sebesar $275,86 \mathrm{~mm}$ dan menghasilkan produksi padi sebanyak 854,95 ton, sementara pada waktu penanaman kedua curah hujan rata-rata 160,42 $\mathrm{mm}$ dan menghasilkan produksi padi sebanyak 844,95 ton, dan untuk mendapatkan hasil produksi yang terbaik yaitu minimal curah hujan ratarata $200 \mathrm{~mm} / \mathrm{sekali}$ panen.

Untuk mendapatkan hasil produksi/panen yang baik rata-rata curah hujan berkisar antara 1500-2000 $\mathrm{mm} /$ tahun jika di bawah dari itu maka produksi tidak bagus, kemudian jika curah hujan kurang dari $200 \mathrm{~mm} / \mathrm{bulan}$ maka juga akan berdampak pada terhadap produksi

Tabel 3.5 Produksi Padi dan curah hujan tahunan

\begin{tabular}{lllll}
\hline No. & Tanam Hingga Panen & Data Curah & Curah hujan & Produktsi \\
& Pada Tahun 2015 & Hujan Bulanan & rata-rata & Ton
\end{tabular}

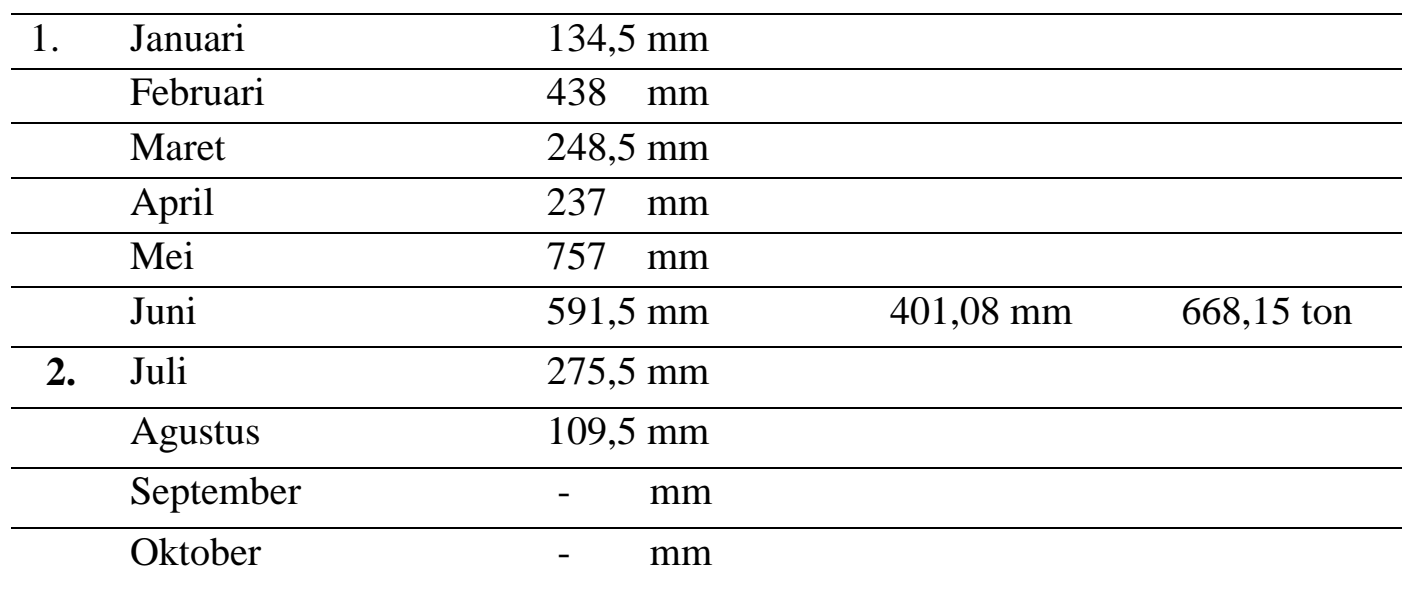




\begin{tabular}{rllll}
\hline November & 55 & $\mathrm{~mm}$ & & \\
\hline Desember & 458 & $\mathrm{~mm}$ & $149,7 \mathrm{~mm}$ & 652,15 ton \\
\hline Total & $\mathbf{2 , 7 5 6 , 5} \mathbf{~ m m}$ & $\mathbf{5 5 0 , 7 4} \mathbf{~ m m}$ & $\mathbf{1 . 3 2 0 , 3}$ ton \\
\hline
\end{tabular}

Data : Diolah dari Hasil penelitian 2017

Dari Tabel diatas dapat dilihat bahwa Pada bulan Januari curah hujannya sebanyak $134,5 \mathrm{~mm}$, bulan Februarisebanyak $438 \mathrm{~mm}$, bulan maret curah hujannya $248,5 \mathrm{~mm}$, bulan april curah hujannya $237 \mathrm{~mm}$, bulan mei curah hujannya $757 \mathrm{~mm}$, dan bulan juni curah hujannya $591,5 \mathrm{~mm}$, kemudian penanaman kedua, mulai di lakukan pada bulan juli curah hujannya sebanyak $275 \mathrm{~mm}$, bulan agustus curah hujannya $109,5 \mathrm{~mm}$, di susul pada bulan September tidak terjadi curah hujan, bulan oktober curah hujannya sebanyak - mm, bulan November sebanyak $55 \mathrm{~mm}$, dan bulan Desember sebanyak $458 \mathrm{~mm}$.

Maka Untuk Mengetahui nilai Q maka dapat dihitung dengan rumus sebagai berikut : $100 \%$

$$
\mathrm{Q}=\frac{\text { Jumlah rata-rata bulan kering }}{\text { jumlah rata-rata bulan basah }} \mathrm{X}
$$

$$
\mathrm{Q}=\frac{3}{7} \times 100 \%
$$

$$
\text { Nilai } Q=42,85 \%
$$

Maka dapat di ketahui bahwa pada tabel diatas menunjukkan bahwa curah hujan bertipe iklim C Yaitu Agak Basah, vegetasinya hutan rimba.

Sehinga dapat dilihat pada tabel diatas bahwa produksi padi pada tahun 2015, dimana curah hujan rata-rata pada waktu penanaman pertama sebesar 401,08 mm dan menghasilkan produksi padi sebanyak 668,15 ton, sementara pada waktu penanaman kedua curah hujan rata-rata $149,7 \mathrm{~mm}$ dan menghasilkan produksi padi sebanyak 625,15 ton, dan untuk mendapatkan hasil produksi yang terbaik yaitu minimal curah hujan ratarata $200 \mathrm{~mm} /$ sekali panen.

Untuk mendapatkan hasil produksi/panen yang baik rata-rata curah hujan berkisar antara 1500-2000 $\mathrm{mm} /$ tahun jika lebih dan kurang yang dimaksud maka produksi tidak bagus, atau bisa saja gagal panen, kemudian jika curah hujan kurang dari $200 \mathrm{~mm} /$ bulan maka juga akan berdampak pada terhadap produksi 
Tabel 3.6 Produksi padi dan curah hujan tahunan

\begin{tabular}{|c|c|c|c|c|}
\hline No. & $\begin{array}{l}\text { Tanam Hingga Panen } \\
\text { Pada Tahun } 2016\end{array}$ & $\begin{array}{l}\text { Data Curah } \\
\text { Hujan Bulanan }\end{array}$ & $\begin{array}{l}\text { Curah hujan } \\
\text { rata-rata }\end{array}$ & $\begin{array}{l}\text { Produktsi } \\
\text { Ton }\end{array}$ \\
\hline \multirow[t]{6}{*}{1.} & Januari & $97,1 \mathrm{~mm}$ & & \\
\hline & Februari & $295,0 \mathrm{~mm}$ & & \\
\hline & Maret & $359,3 \mathrm{~mm}$ & & \\
\hline & April & $267,4 \mathrm{~mm}$ & & \\
\hline & Mei & $108,7 \mathrm{~mm}$ & & \\
\hline & Juni & $266,8 \mathrm{~mm}$ & $232,38 \mathrm{~mm}$ & 911,6 ton \\
\hline \multirow[t]{7}{*}{2.} & Juli & $162,3 \mathrm{~mm}$ & & \\
\hline & Agustus & $49,0 \mathrm{~mm}$ & & \\
\hline & September & $80,5 \mathrm{~mm}$ & & \\
\hline & Oktober & $187,9 \mathrm{~mm}$ & & \\
\hline & November & $41,0 \mathrm{~mm}$ & & \\
\hline & Desember & $198 \mathrm{~mm}$ & $119,78 \mathrm{~mm}$ & 897,6 ton \\
\hline & Total & $1.769 \mathrm{~mm}$ & $352,16 \mathrm{~mm}$ & $1.809,2$ ton \\
\hline
\end{tabular}

Data : Diolah dari Hasil penelitian 2017

Dari Tabel diatas dapat dilihat bahwa Pada bulan Januari curah hujannya sebanyak $97,1 \mathrm{~mm}$, bulan Februarisebanyak 295,0 mm, bulan maret curah hujannya $359 \mathrm{~mm}$, bulan april curah hujannya $267,4 \mathrm{~mm}$, bulan mei curah hujannya $108,7 \mathrm{~mm}$, dan bulan juni curah hujannya $266,8 \mathrm{~mm}$, kemudian penanaman kedua, mulai di lakukan pada bulan juli curah hujannya sebanyak $162,3 \mathrm{~mm}$, bulan agustus curah hujannya $49,0 \mathrm{~mm}$, di susul pada bulan September curah hujannya $80,5 \mathrm{~mm}$, bulan oktober curah hujannya sebanyak $187,9 \mathrm{~mm}$, bulan November sebanyak $41,0 \mathrm{~mm}$, dan bulan Desember sebanyak 198 mm.Maka Untuk Mengetahui nilai Q maka dapat dihitung dengan rumus sebagai berikut :

$$
\begin{gathered}
\mathrm{Q}=\frac{\text { Jumlah rata }- \text { rata bulan kering }}{\text { jumlah rata-rata bulan basah }} \times 100 \% \\
\mathrm{Q}=\frac{2}{10} \times 100 \% \\
\text { Nilai } \mathrm{Q}=20 \%
\end{gathered}
$$

Maka dapat di ketahui bahwa pada tabel diatas menunjukkan bahwa curah hujan bertipe iklim B Yaitu Basah, vegetasinya hutan hujan tropis.

Sehinga dapat dilihat pada tabel diatas bahwa produksi padi pada tahun 2016, dimana curah hujan rata-rata pada waktu penanaman pertama sebesar 232,38 mm dan menghasilkan produksi padi sebanyak 911,6 ton, sementara pada waktu penanaman kedua curah hujan rata-rata 119,78 $\mathrm{mm}$ dan menghasilkan produksi padi sebanyak 897,6 ton, dan untuk mendapatkan hasil produksi yang 
terbaik yaitu minimal curah hujan ratarata $200 \mathrm{~mm} / \mathrm{sekali}$ panen.

Untuk mendapatkan hasil produksi/panen yang baik rata-rata curah hujan berkisar antara 1500-2000 $\mathrm{mm} /$ tahun jika lebih dan kurang yang dimaksud maka produksi tidak bagus, atau bisa saja gagal panen, kemudian jika curah hujan kurang dari $200 \mathrm{~mm} /$ bulan maka juga akan berdampak pada terhadap produksi.

\section{PEMBAHASAN}

Desa Lambo-Lemo Merupakan sebuah Desa yang Secara administrative termasuk dalam bagian dari Kecamatan Samaturu Kabupaten Kolaka Provinsi Sulawesi Tenggara. Desa Lambo-Lemo Terletak dibagian tengah Kabupaten Kolaka yang juga termasuk desa yang kondisi alamnya atau tanahnya subur, dan sangat cocok untuk lahan pertanian. Hal ini menandakan bahwa kehidupan masyarakat Desa Lambo-Lemo Akan lebih baik lagi bila ada perhatian, Dukungan dan bantuan yang diberikan oleh pemerintah daerah khususnya pemerintah setempat dalam mengembangkan dan memanfaatkan potensi Desa Lambo-lemo sebagai wujud tanggung jawabnya dalam mensejahterakan masyarakatnya.

$$
\text { Desa Lambo - lemo }
$$
merupakan bagian dari wilayah ibu Kota Kabupaten Kolaka Provinsi Sulawesi Tenggara, dan Desa LamboLemo juga bisa dikatakan sebagai penghasil padi yang banyak setiap tahunnya, Karena Hampir semua masyarakatnya bertani padi. Hal ini dikarenakan kondisi alam atau tanahnya yang subur dan cocok untuk wilayah pertanian khususnya tanaman padi, Karena selain mudah untuk dikerjakan juga gampang untuk ditanam oleh masyarakat karena tidak susah untuk mendapatkan bibit, juga sudah menjadi kebiasaan. Padi juga gampang didapatkan untuk pemasarannya,dan banyak diminati dan juga kemudian menjadimakanan pokok di Indonesia salah satunya di kabupaten Kolaka Kecamatan Samaturu Desa Lambo-Lemo Ini.Jarak antara daerah penelitian (Desa LamboLemo) dengan kantor Kecamatan Samaturu adalah sekitar $3 \mathrm{~km}$, sedangkan dengan Kantor Bupati Kolaka sekitar 36 km.

Dilihat dari keadaan Alamnya, Desa Lambo-lemo merupakan daerah yang didominasi daerah perbukitan Dan Lahan pertanian Sawah yang cukup luas Sehingga kebanyakan dari penduduk lokal bekerja sebagai petani. Kondisi ini di dukung dengan Tanahnya yang bisa ditumbuhi tanaman padi, yang dapat dimanfaatkan oleh penduduk setempat. Selain tanaman padi tanah di Desa Tersebut bisa ditanami segala macam tanaman yang bisa di manfaatkan oleh penduduk sebagai penyambung hidup, misalnya tanaman sayur-sayuran yang biasa di jual dipasaran, juga tanaman jangka panjang, seperti kelapa, jambu mente, Rambutan,Coklat,Cengkeh, Merica, dan lain-lain.

Berdasarkan keadaan topografi, Desa Lambo-lemo juga memiliki lingkungan alam yang terdiri dari dataran rendah, dan dataran tinggi. Hal ini menyebabkan penduduk banyak mengambil profesinya sebagai petani, karena hampir semua wilayah Desa Lambo-Lemo dijadikan sebagai wilayah perkebunan dan pertanian penduduk. Area perkebunan ditandai 
dengan keberadaan berbagai jenis tanaman seperti tanaman kelapa, mangga, tanaman coklat, cengkeh, dan merica. Dan area pertanian ditandai dengan tanaman Padi, jagung, kacangkacangan, sayur, dan ubi-ubian.

\section{KESIMPULAN}

Sudah dijelaskan sebelumnya bahwa dampak perubahan curah hujan sangat berpengaruh pada keadaan tanaman khususnya tanaman padi. Selain karna faktor curah hujan yang tinggi, yang dapat mempengaruhi produktivitas tanaman padi, juga Keadaan tanah pertanian merupakan bagian yang dapat mempengaruhi hasil produksi padi di desa lambo-lemo. Dimana tanaman padi sangat toleran dan tanaman padi dapat tumbuh dengan baik di daerah yang berhawa panas dan banyak mengandung uap air dengan hujan rata-rata $200 \mathrm{~mm}$ bulan - 1 atau lebih, dengan distribusi selama empat bulan, selain itu juga Hama merupakan hewan yang dapat merusak tanaman pertanian. Hama juga dapat tergolong sebagai berikut,seperti hama yang berbentuk berung, ulat, dan berbentuk hewan, dan lain sebagainya yang dapat merusak atau menurunkan hasil panen terhadap tanaman pertanian dalam hal ini tanaman padi.

Produksi padi rata-rata mulai pada tahun 2012-2016 berdasarkan data yang ada 780,54 ton ini merupakan produksi yang bagus di dukung dengan curah hujan yang baik dengan curah hujan rata-rata 198,874 $\mathrm{mm}$.

\section{DAFTAR PUSTAKA}

Arikunto, Suharsimi, 2002, Prosedur suatu pendekatan praktek. Jakarta PT. Rineka Cipta
Arsyad, S. 2010. Konservasi Tanah Dan Air. Institut Pertanian Bogor (IPB). Bogor.

BMKG 2017, Cuaca, iklim, dan gempa bumi indonesia (Badan Metereologi, Klimatologi dan Geofisika). Cabang Kolaka.

Direktorat Jenderal Pengairan. 1982. Direktorat Bina Program. Departemen Pekerjaan Umum. Studi Perencanaan dan Pengembangan Sumber sumber Air Wilayah Sungai Way Pisang. Laporan Akhir. Laporan Utama.

Esterber, Kristin G., 2002. Qualitative Methods in social Research,Mc,Graw Hill, : New York.

Kasmadi, 2013. Panduan modern penelitian kuantitatif.

Alfabeta: Bandung.

Linsley, R.K. dan Joseph, B.F. 1985. Teknik Sumber Daya Air. Erlangga : Jakarta.

Riduwan. 2009. Dasar-Dasar Statistika. Bandung : Alfabeta

Sugiyono, 1997. Metodologi penelitian Administrasi. Yogyakarta : CV Alfabeta.

Sugiyono, 2013. Metode Penelitian Kuantitatif, Kualitatif dan $R$ \& $D$. CV. Alfabeta, Bandung. 